\title{
Rocky intertidal macrobenthic communities across a large-scale estuarine gradient
}

\author{
LUIS GIMÉNEZ ${ }^{1,2}$, ANA INÉS BORTHAGARAY ${ }^{1,3}$, MARCEL RODRÍGUEZ ${ }^{1}$, \\ ALEJANDRO BRAZEIRO ${ }^{4}$ and ALVAR CARRANZA ${ }^{1,5}$
}

${ }^{1}$ Sección Oceanología, Facultad de Ciencias, Iguá 4225, 11400 Montevideo, Uruguay.

${ }^{2}$ School of Ocean Sciences, Bangor University, LL59 5AB, Menai Bridge, UK. E-mail: 1.gimenez@ bangor.ac.uk ${ }^{3}$ Instituto de Ecología y Biodiversidad, Casilla 653 Santiago, Chile. Departamento de Ecología and Centro de Estudios Avanzados en Ecología y Biodiversidad, Pontificia Universidad Católica de Chile, Casilla 114-D, Santiago, Chile. ${ }^{4}$ Departamento de Ecología, Facultad de Ciencias, Iguá 4225, 11400 Montevideo, Uruguay.

${ }^{5}$ UNDECIMAR, Facultad de Ciencias, Iguá 4225, 11400 Montevideo, Uruguay.

SUMMARY: We evaluated relationships between (1) salinity and species richness and (2) frontal zones and community structure for the rocky intertidal macrobenthic community of the Uruguayan coast. A large-scale sampling design (extent $\sim 500 \mathrm{~km}$ ) covering 9 rocky shores across 3 intertidal levels was performed between September and November 2002. The linear relationship between salinity and species richness (minimum at the freshwater extreme) and the lack of correlation between variation in salinity and richness rejected two previous empirical models, explaining variations in species richness along the salinity gradient. Other factors (e.g. turbidity) may explain this discrepancy. The estuarine front defined two communities-freshwater and estuarine-marine-differing in species composition and richness. The freshwater community was characterised by low richness and few individuals confined to crevices or tide pools, and must be structured by physical processes (e.g. desiccation); the estuarine-marine community, with individuals occupying almost all available substrata, must be structured by both physical and biological processes. A marine front, separating estuarine and marine habitats, had a weak effect on community structure although estuarine and marine assemblages differed according to species characterising different functional groups. We conclude that the position of the estuarine frontal zones is important for explaining largescale patterns of community structure in the study area.

Keywords: community structure, diversity, estuaries, scale, front.

RESUMEN: COMUNIDADES MACROBENTÓNICAS DEL INTERMAREAL ROCOSO A LO LARGO DE UN GRADIENTE ESTUARINO DE GRAN ESCALA. - En este trabajo evaluamos las relaciones entre (1) la salinidad y la riqueza específica, y (2) las zonas frontales y la estructura de la comunidad macrobentónica del intermareal rocoso de la costa uruguaya. Un diseño de muestreo de gran escala, aplicado entre septiembre y noviembre de 2002, cubrió 9 puntas rocosas y 3 niveles intermareales. La relación lineal entre la riqueza específica y la salinidad (mínima riqueza hacia el extremo dulceacuícola del gradiente) y la ausencia de relación entre la riqueza y las variaciones temporales en la salinidad descartaron dos modelos previos que intentaban explicar las variaciones de riqueza a lo largo del gradiente salino. Otros factores (e.g. turbidez) podrían explicar estas discrepancias. El frente salino definió dos comunidades, de agua dulce y estuarina-marina, diferenciadas en su composición y riqueza específica. La comunidad dulceacuícola se caracterizó por pocos individuos, confinados a grietas o piletas de marea y estaría estructurada por procesos físicos (e.g. desecación). La comunidad estuarina-marina, compuesta por un mayor número de especies, ocupando casi la totalidad del sustrato disponible, estaría estructurada por procesos físicos e interacciones biológicas. El frente marino, que separa los hábitats marinos y estuarinos, tuvo un efecto reducido sobre la estructura de la comunidad, aunque se pudieron diferenciar agrupaciones marinas y estuarinas a partir de especies de diferentes grupos funcionales. A partir de estos resultados, concluimos que la posición del frente estuarino es importante para explicar los patrones de gran escala en la comunidad estudiada.

Palabras clave: estructura comunitaria, diversidad, estuarios, escalas, frentes. 


\section{INTRODUCTION}

The development of most ecological theory relies on the study of small-scale patterns of distributions (Schneider, 1994). However, due to the scale-dependent nature of the processes shaping the communities, it is not possible to infer patterns or mechanisms operating at larger scales from the knowledge obtained at small scales (Hughes et al., 1999; Fraschetti et al., 2005; Giménez et al., 2005). Thus, the starting point to uncover regional and global phenomena involves the determination of large-scale (hundreds to thousands of $\mathrm{km}$ ) patterns of distribution of species and community attributes. Due to technical difficulties, large-scale patterns of distribution in the marine habitat are not well-known, especially in the southern hemisphere. In particular, in intertidal habitats, research on large-scale variability in populations and communities focuses on latitudinal gradients in coastal oceanic areas, associated with gradients in solar irradiance, temperature, disturbance history or production (Hughes et al., 1999; Bustamante and Branch, 1996; Broitman et al., 2001; Benedetti-Cecchi, 2001).

The effect of salinity gradients on rocky-shore benthic communities is less well-known. Most studies of gradients in estuarine areas are concerned with small-scale patterns and soft-sediment fauna (but see Wallentinus, 1991). In soft sediments, gradients in species richness are observed along estuaries, with a minimum salinity of around 3-4 (reviewed in Remane and Schlieper, 1971). Correlations between macrofaunal groups and salinity have been found in several estuaries (Mannino and Montagna, 1997; Ysebaert et al., 2003). Macrofaunal richness may reach minimum values (1) at an ecophysiological boundary (horohalinicum) at a salinity of 4-8 (Remane and Schlieper, 1971), or (2) at sites characterised by high variability in salinity (Attrill, 2002).

The Uruguayan coast gives a unique opportunity to study how large-scale patterns of distribution of rocky intertidal benthic organisms change in an estuarine gradient. A large-scale salinity gradient of about $500 \mathrm{~km}$ extension is caused by the Río de la Plata and its estuarine zone. The estuary of Río de la Plata is by far the largest of all estuaries of the western South Atlantic, draining the second largest basin of South America (Guerrero et al., 1997a; Mianzan et al., 2001). This is a coastal plain estuary with a quasi-permanent salt-wedge regime and a river funnel $280 \mathrm{~km}$ long and 80 to $230 \mathrm{~km}$ in cross-section.
Surface salinity varies seasonally, and is controlled by winds, river discharge and Coriolis force, while bottom salinity does not vary seasonally and is controlled by bathymetry (Guerrero et al., 1997a).

The estuary is divided into an inner fluvial sector and an outer mixo-haline sector by an estuarine frontal zone located within two front-lines: the main turbidity front and the secondary main front (Severov et al., 2003; Lappo et al., 2005). This frontal zone moves river- and seaward depending on the river flow and winds, and its location roughly matches the 0 and 10 surface isohalines, slightly seaward of the bottom salinity front (Framiñan and Brown, 1996; Nagy et al., 2002). There is in addition a surface marine front located seaward, extending for several kilometres and occupying a wider area.

Our objective was to investigate the large-scale patterns of horizontal variation in community structure of the rocky intertidal communities along the freshwater-estuarine-marine gradient of the Río de la Plata and Atlantic Uruguayan coastline. For this region studies on intertidal rocky shore are scarce (Maytía and Scarabino 1979, Borthagaray and Carranza, 2007). We explored the relationships between salinity and species richness and investigated whether macrobenthic community structure varied in relation to the estuarine and marine fronts.

\section{MATERIALS AND METHODS}

\section{Study area}

The study area comprised nine rocky shores (= sites) selected at random so that three sites were sampled in each sector of the coast (west-freshwater, central-estuarine, and east-oceanic). However, we avoided sites located near the main coastal cities (Montevideo, Piriápolis, Punta del Este, La Paloma) in order to reduce effects of human disturbance on the observed patterns. From west to east, the sites were: Colonia, Punta del Rosario, Punta Espinillo, Atlántida, Punta Colorada, Punta Ballena, José Ignacio, La Pedrera, and Santa Teresa (Fig. 1). Field sampling was carried out in September-November 2002 at low tide.

Ten random transects perpendicular to the shoreline were defined along each rocky site, usually separated 10-50 m depending on the extent of the rocky habitat, which varied between 100 and $2000 \mathrm{~m}$ of alongshore extension (Fig. 1). Within each transect, 

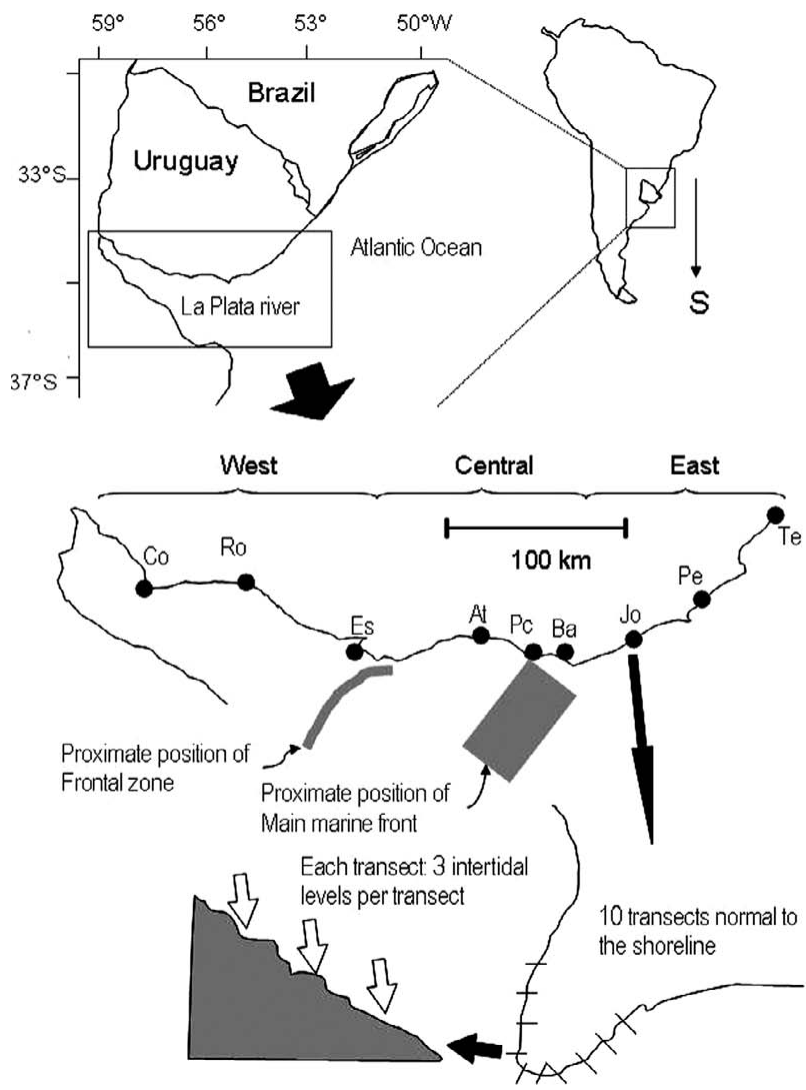

FIG. 1. - Geographic location of rocky intertidal sites (circles) and sampling design at sites located within 3 sectors of the coast. At each site, 10 random transect perpendicular to the coast were sampled; samples within each transect covered three different intertidal levels. Co: Colonia, Ro: Rosario, Es: Punta Espinillo, At: Atlántida, Pc: Punta Colorada, Ba: Punta Ballena, Jo: José Ignacio, Pe: La Pedrera, Te: Santa Teresa.

three contiguous intertidal levels were sampled. These levels were defined biologically, namely the mussel-macroalgal zone (lower intertidal), the barnacle zone (middle intertidal) and the lichen zone (upper intertidal).

For each level, within each transect we defined an area (= station) located in the centre of each biological zone delimited by a frame of $0.1 \mathrm{~m}^{2}$ surface area (Fig. 1). The biological zones are narrow on the Uruguayan coast (1-3 m depending on substrate slope), most likely due to the microtidal regime. Organisms were collected at stations in the lower intertidal zone by scraping until all organisms were removed; individuals at stations in the barnacle zone and the upper intertidal zone were identified in situ. When crevices, holes or boulders were included in our samples we inspected them visually and collected individuals by hand.

Collected organisms were fixed in 5\% formalin and taken to the laboratory for identification. Species identification was done following appropriate keys and updated taxonomic lists (for molluscs Rios [1994], Scarabino [2004] and Scarabino et al. [2006]; for polychaetes Nonato and Amaral [1979]; for crustaceans Boschi et al. [1991]; and for macroalgae Coll and Oliveira [1999]). At all sites, salinity was measured with a Horiba U-10 Multiparameter sensor.

\section{Data analysis}

Data were analysed as presence-absence per transect and by proportion of occurrence per site (= number of transect where a species was present divided by 10). There were two reasons for collecting qualitative but not quantitative data: Firslty, it was not possible to quantify the area sampled within several microhabitats such as crevices and holes. Secondly, in order to reduce any temporal source of variation in the data, we attempted to survey all sites as fast as possible. Since abundance of rocky shore organisms varies considerably at smaller scales (Fraschetti et al., 2005), reliable quantitative data can be only obtained from replicate samples within each transect and level, thereby increasing the time necessary to cover the whole coast. On the other hand, at small scales patterns of presence/absence may not be as variable as patterns of abundance.

Presence/absence matrices per transect were constructed by pooling the data from each of the three sampled intertidal levels. The reason for this was that in the west sector, barnacles were not present and organisms were found only in tidal pools. In this sector, biological levels were not clear at all, so comparisons of fauna per biological level were not possible.

We tested the hypothesis that species composition varied among sectors using canonical analysis of principal coordinates (CAP: Anderson and Willis, 2003) using the Jaccard index of similarity. Analyses were run using all species as well as separately by functional groups: macroalgae, sessile fauna and mobile fauna.

For macroalgal data we were not able to reach the species level as for faunal data, so our analysis based solely on that dataset may show a blurred picture of the assemblage structures. In order to check our results with an independent dataset, we used that from the annotated list of macroalgal species of the Uruguayan coast given by Coll and Oliveira (1999). Data provided by Coll and Oliveira (1999) consist in presence/absence of 69 species sampled from 27 sites located along the central and east sectors of the Uruguayan coast. For the multivariate analysis 
of Coll and Oliveira's dataset we constrained our dataset to 55 species present at more than one site, resulting in 21 sites containing at least 1 species. We constructed a matrix of presence/absence ( 55 species x 21 sites) and used CAP and the Jaccard index to determine whether macroalgal assemblages differed between regions.

Relationships between species richness and salinity were analysed with the Pearson correlation and linear regression (Zar, 1996). We recognise that our records of salinity reflected an instantaneous situation and may not represent the most common conditions at each site. In order to solve this problem, we evaluated relationships between salinity and species richness using historical data from the Uruguayan coast, taken from the hydrographical atlas of Guerrero et al. (1997b) comprising 2939 stations from 39 cruises carried out during the last 30 years. These data are provided as mean, minimum and maximum values per season in quadrants of $0.5^{\circ}$ length: for our comparisons we therefore used the mean, minimum and maximum values of salinity from the quadrants that included our sampling sites: these values are given in Table 1. We used Moran's I to measure the spatial autocorrelation in the regression residuals, treating the latitude and longitude for each rocky point as the $x-y$ coordinates. When regression residuals are spatially autocorrelated, an explicit spatial regression is needed, in order to control for bias that spatially structured data may cause. However, when regression residuals are not spatially autocorrelated, further analysis by spatial regression is not necessary or informative (Diniz-Filho et al., 2002). Regression residuals were examined for spatial autocorrelation based on Moran's I for a connectivity matrix constructed under the distance criterion. All spatial statistics were carried out using SAM v1.1 (Rangel et al., 2006), freely available at www.ecoevol.ufg.br/sam. Cumulative richness curves were used to check how sampling effort affected our estimations of total richness and richness per sector (Gotelli and Entsminger, 2004).

\section{RESULTS}

Total species richness was 47 species $( \pm$ conf. int. $=42-49$ ) and increased from west to east (Fig. 2a); this was most notable for sessile fauna and macroalgae. Rarefaction curves showed a similar pattern (Fig. 2b) so that the species richness increased from west to east: in the west sector the predicted richness (13 species, \pm conf. int.: $11-15$ species) was lower than that of the central sector (25, \pm conf. int: 24-26) and east sector (32 species \pm conf. int.:29-34). Rarefaction curves showed that we captured most of the species, with exception of the west sectors; however, in the west sector, we had many transects devoid of organisms.

TABLE 1. - Salinity on the Uruguayan coast and correlations with species richness. (a) Salinity per site: the first four columns represent the average values for spring, for all seasons, and the maximum and minimum seasonal averages (source: Guerrero et al., 1997b); the last column contains the data collected in this study. (b) Correlations between species richness and salinity using data from the respective columns: all correlations are significant $(P<0.05)$ except the one between macroalgae richness and mean salinity in spring $(P=0.052)$. $(\mathrm{c})$ Moran's regression residuals.

\begin{tabular}{|c|c|c|c|c|c|}
\hline & Spring & Year & Maximum & Minimum & Present study \\
\hline \multicolumn{6}{|l|}{ (a) Sites } \\
\hline Colonia & 0.02 & 0.14 & 0.38 & 0.02 & 0.0 \\
\hline Rosario & 0.01 & 0.23 & 0.39 & 0.01 & 0.0 \\
\hline Punta Espinillo & 0.66 & 6.14 & 12.00 & 0.66 & 1.5 \\
\hline Atlántida & 22.01 & 16.62 & 22.01 & 13.14 & 8.0 \\
\hline Punta Colorada & 26.92 & 19.84 & 26.92 & 15.07 & 13.5 \\
\hline José Ignacio & 25.04 & 22.83 & 25.04 & 20.04 & 19.6 \\
\hline La Pedrera & 23.17 & 25.81 & 28.79 & 23.17 & 19.5 \\
\hline Santa Teresa & 25.65 & 25.94 & 32.52 & 22.34 & 24.0 \\
\hline \multicolumn{6}{|c|}{ (b) Correlation $\left(\mathrm{R}^{2}\right)$ with species richness } \\
\hline Total & 0.76 & 0.87 & 0.74 & 0.93 & 0.94 \\
\hline Sessile & 0.86 & 0.84 & 0.74 & 0.87 & 0.88 \\
\hline Mobile & 0.58 & 0.61 & 0.47 & 0.68 & 0.78 \\
\hline Macroalgae & 0.36 & 0.66 & 0.59 & 0.71 & 0.60 \\
\hline \multicolumn{6}{|c|}{ (c) Moran's I for regression residuals } \\
\hline Total & 0.35 & 0.16 & 0.26 & -0.23 & 0.45 \\
\hline Sessile & 0.07 & -0.04 & 0.06 & -0.02 & -0.03 \\
\hline Mobile & 0.10 & 0.02 & 0.13 & -0.14 & -0.16 \\
\hline Macroalgae & 0.30 & 0.40 & 0.39 & 0.33 & 0.18 \\
\hline
\end{tabular}



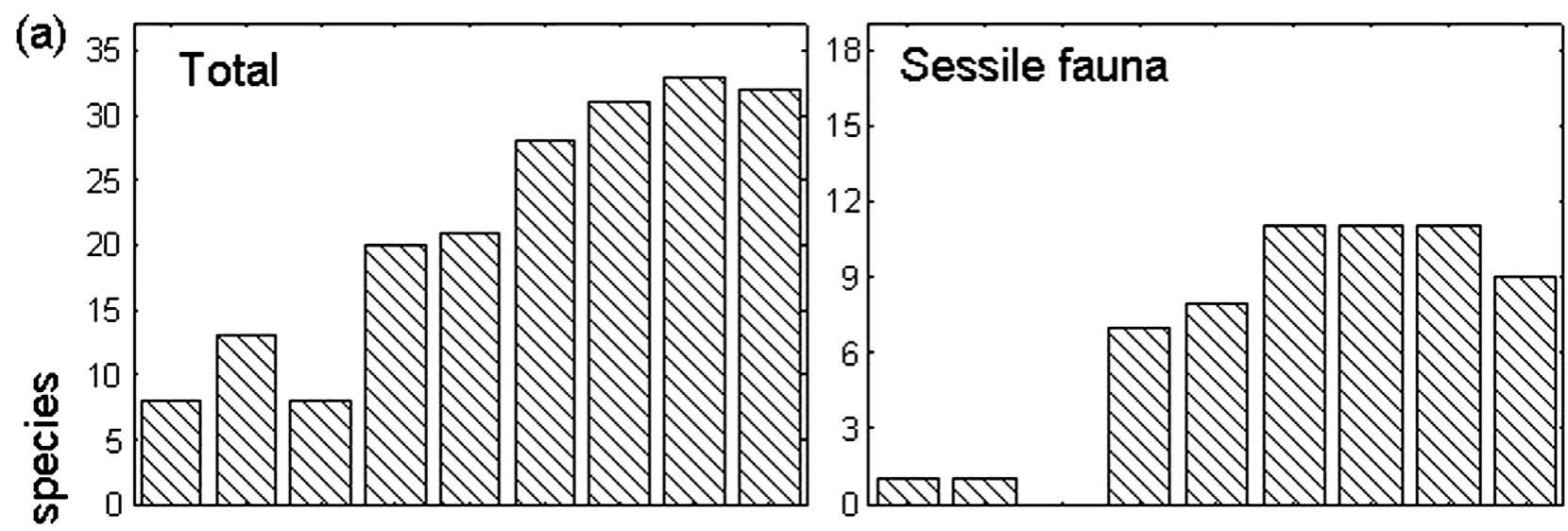

늠
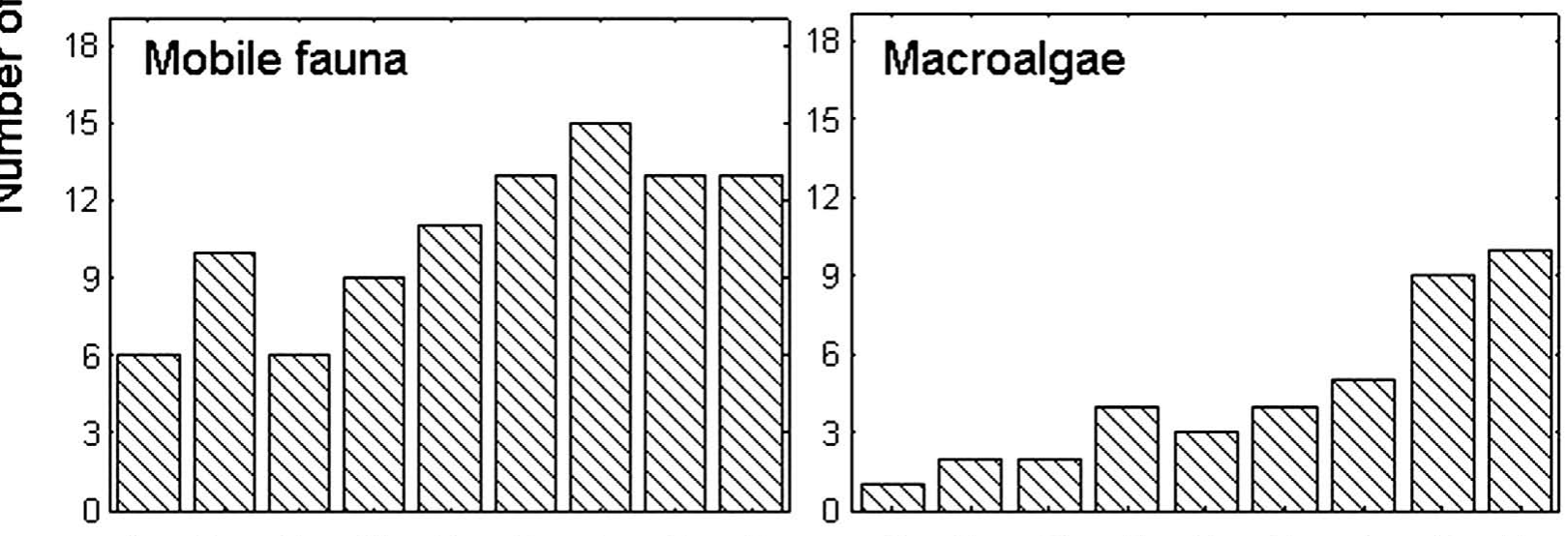

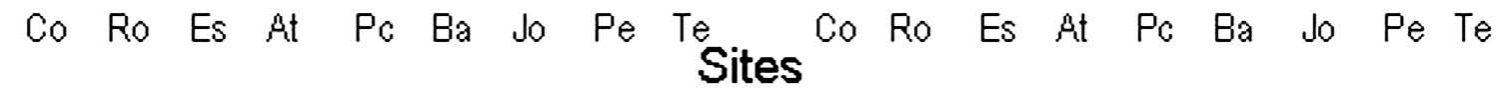

(b)

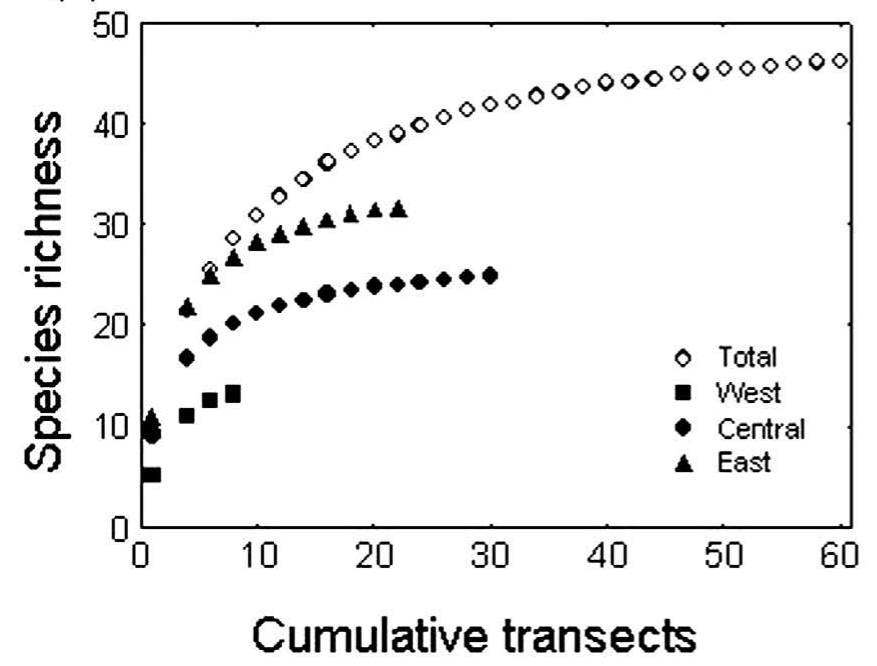

FIG. 2. - Species richness of the Uruguayan rocky intertidal zone of Río de la Plata and the Oceanic coast. (a) total richness and richness of main benthic groups. Abbreviations of sites are as follows: Co: Colonia, Ro: Rosario, Es: Punta Espinillo, At: Atlántida, Pc: Punta Colorada, Ba: Punta Ballena, Jo: José Ignacio, Pe: La Pedrera, Te: Santa Teresa. (b) Cumulative richness according to the sampling effort.

Species richness was positively correlated with salinity irrespective of the group considered (Fig. 3); a linear model explained a high percentage of variation for total macrobenthos and sessile fauna. Salini- ties obtained from Guerrero et al. (1997b) and those recorded by us are shown in Table 1 . Our values of salinity were slightly lower in comparison with the means per season, including the minimum seasonal 


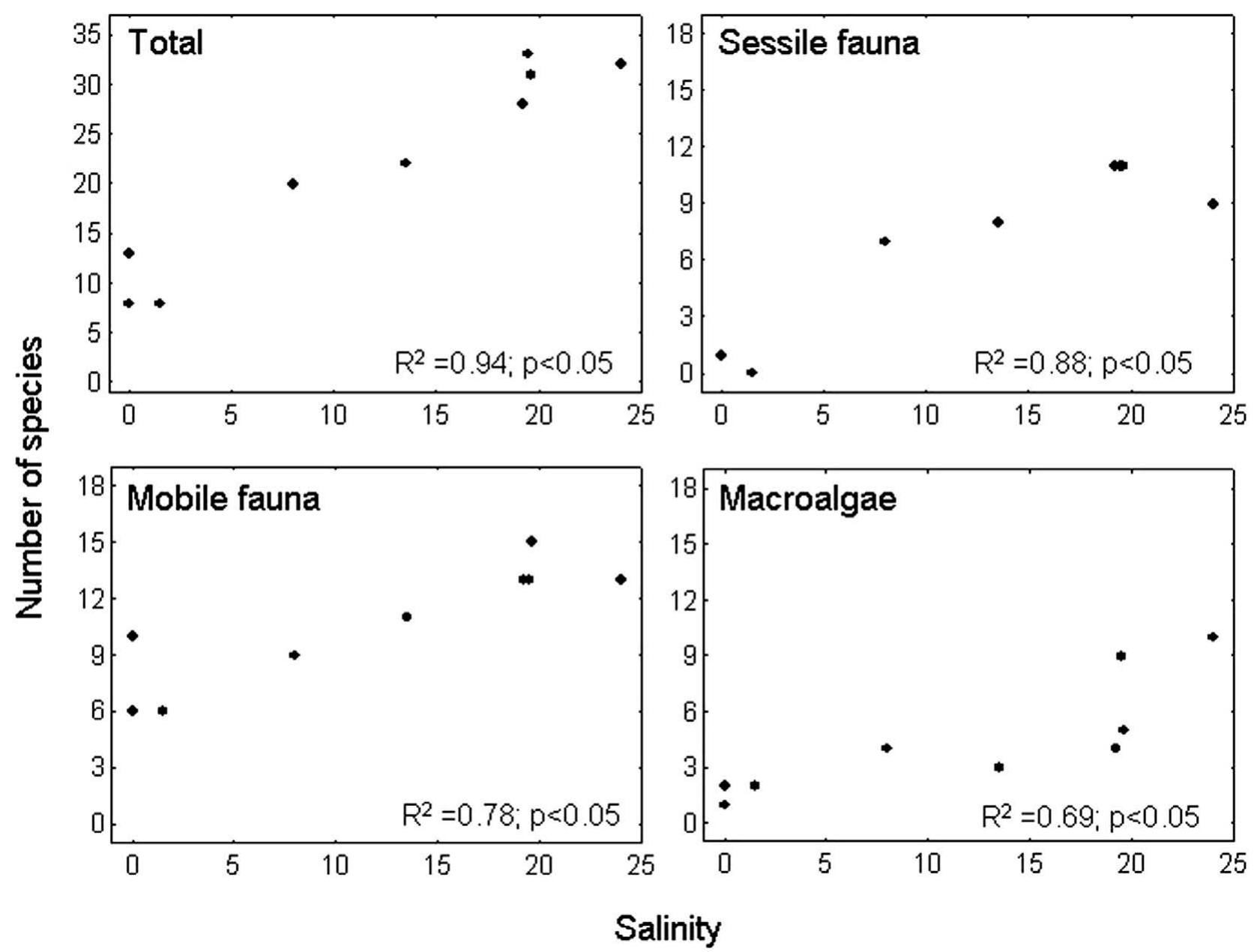

FIG. 3. - Correlations between salinity and species richness in the Uruguayan rocky intertidal of Río de la Plata and the Oceanic coast.

means. However, correlations between the mean values of salinity, spring mean salinity (exception for macroalgae), maximum and minimum salinity and species richness were also highly significant and positive: species richness increased linearly towards sites with high salinity (Table 1). Regression residuals were not significantly spatially autocorrelated in any of the regression analyses ( $P>0.06$ in all cases). On the other hand, correlations between richness and the standard deviation of salinity were not significant (Total richness: $r=0.35$; Sessile: $r=0.40$; Mobile: $r$ $=0.23$; Macroalgae: $r=0.31$; all $P>0.05$ ).

Canonical analysis of principal coordinates used on replicate transects significantly separated freshwater, estuarine and marine sectors with a success (cross-validation test: Anderson and Willis, 2003) of $80 \%, 94 \%$ and $86 \%$ respectively (Fig. 4). Analysis for the functional groups separately (sessile fauna, mobile fauna and macroalgae) showed that the groupings were produced mainly by mobile and sessile fauna. Mobile species (e.g. the snails
Heleobia piscium, Chilina fluminea) and a sessile species (mussel Limnoperna fortunei) characterised the freshwater sector (Fig. 5, left panels). In this sector organisms were found only in crevices and pools or under stones; rock surfaces were devoid of organisms. The species composition at Punta Espinillo also included three decapod crabs, the isopod Pseudosphaeroma platense and the tanaid Sinelobus stanfordi.

The rocky intertidal zone of both estuarine and oceanic sectors exhibited a higher cover of a larger number of species. Here, we also found a clear belt of the barnacle Chthamalus bisinuatus and another of mussels or macroalgae. Common mobile fauna in these sectors were e.g. the polychaete Alitta (Neanthes) succinea, the amphipod Hyale grandicornis and the isopod Idotea balthica, while common sessiles were the mussels Mytilus edulis and Brachidontes rodriguezi (Fig. 5, right panels).

The estuarine sector was characterised by sessile species (e.g. the mussel Brachidontes darwini- 

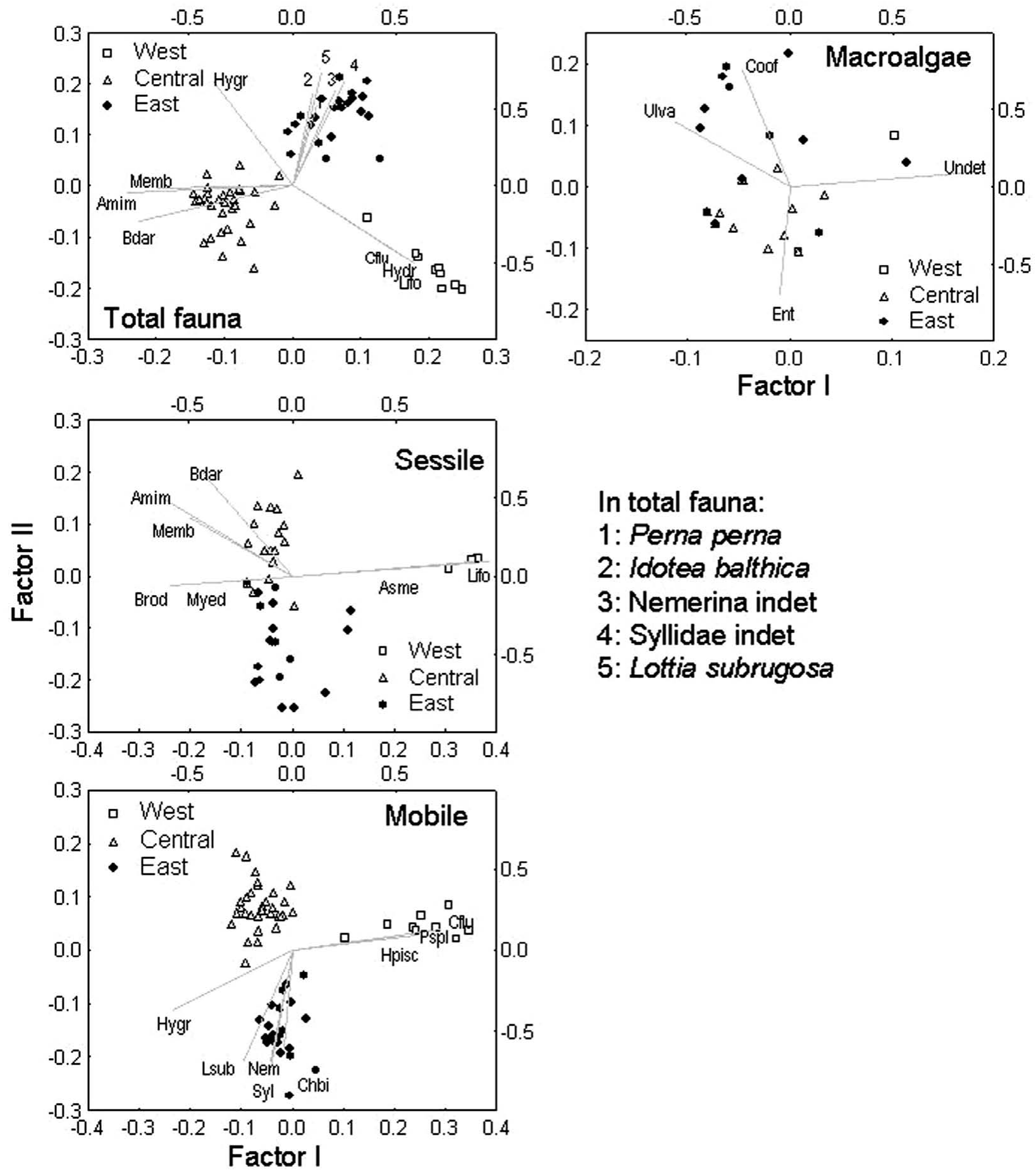

FIG. 4. - Canonical analysis of principal coordinates performed on total fauna and on organisms discriminated by functional groups (sessile fauna, mobile fauna, macroalgae). Abbreviations: Amim: Amphibalanus improvisus, Asme: Asolene megastoma, Bdar: Brachidontes darwinianus, Brod: B. rodriguezi, Cflu: Corbicula fluminea, Chbi: Chtamalus bisinatus, Coof: Coralina officinalis, Ent: Enteromorpha spp., Hpisc: Heleobia piscium, Hygr: Hyale grandicornis, Lifo: Linmoperna fortunei, Lsub: Lottia subrugosa, Memb: Membranipora sp., Myed: Mytilus edulis, Nem: Nemertina indet. Pslp: Pseudosphaeroma platense, Syl: Syllidae indet. Undet: Undetermined lichen.

anus; and the barnacle Amphibalanus (Balanus) improvisus and the bryozoan Membranipora sp., both epibionts on mussels [Fig. 6, left panel]). The marine sector was characterised by mobile species, e.g. two polychaetes species (Halosydnella sp. and a Syllid worm) and Nemertine worms, possibly Lineus rubber, within the algal and mussel canopy. Furthermore, the gastropod Lottia subrugosa (Acmaea subrugosa in Maytía and Scarabino, 1979) was found in crevices within the barnacle belt and 


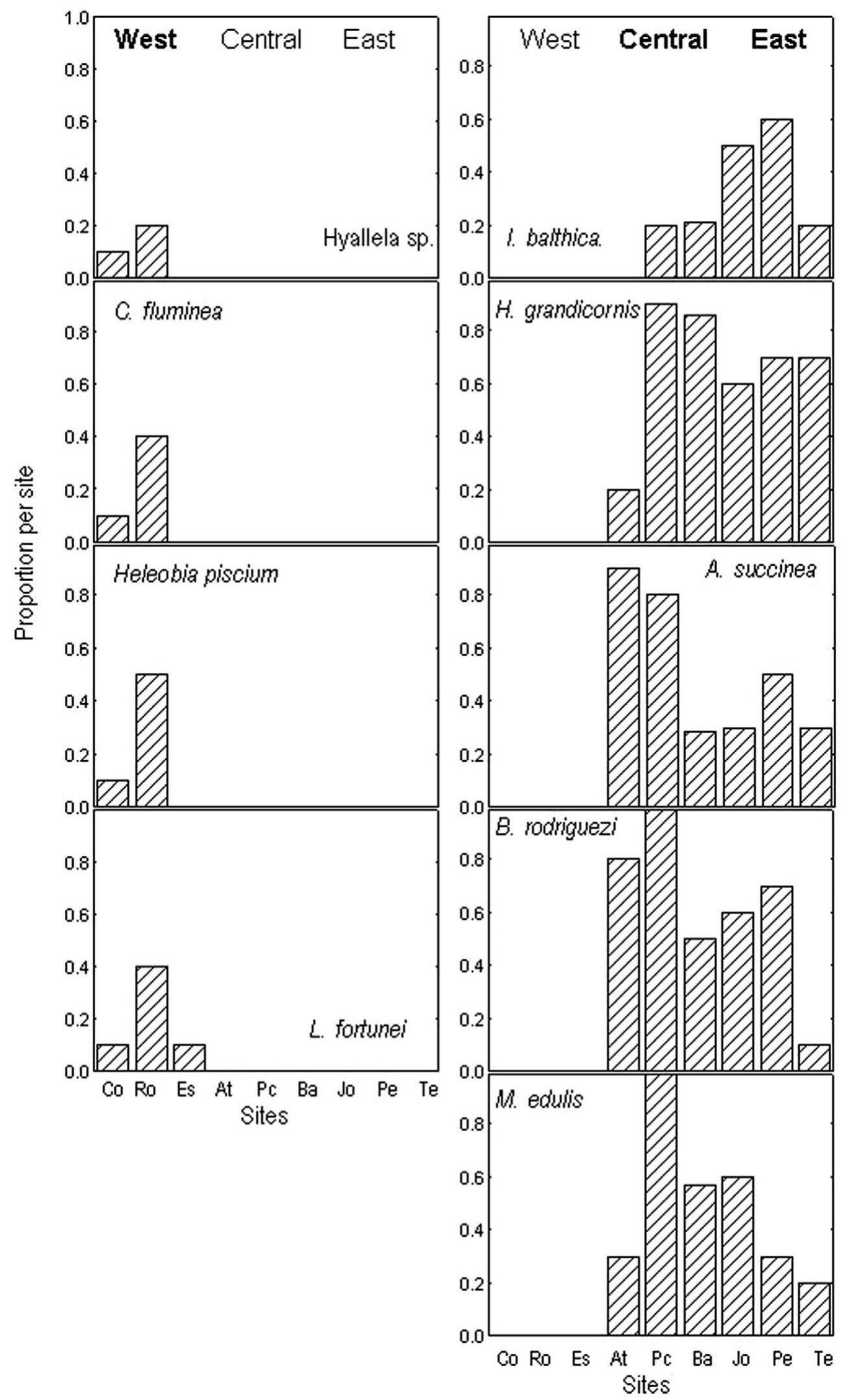

FIG. 5. - Patterns of distribution of species characterising the west (left panels) and central-east sectors (right panels), as proportions (\# transects occupied / total number of transects). A proportion $=1$ indicates that the species was found in all $(=10)$ transects sampled at that site. 

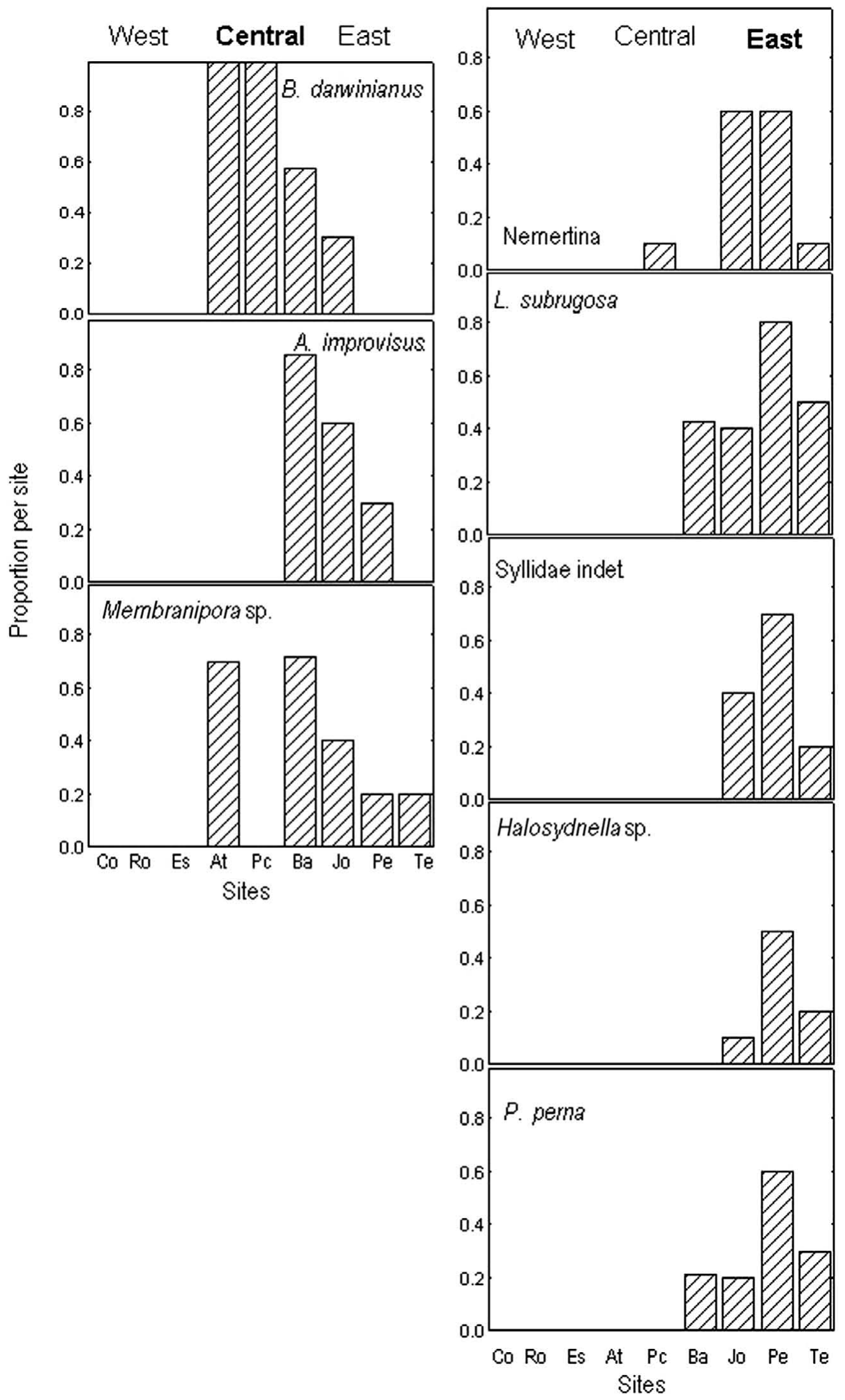

FIG. 6. - Patterns of distribution of species characterising the central (left panels) and east sectors (right panels), as proportions (\# transects occupied / total number of transects). A proportion $=1$ indicates that the species was found in all $(=10)$ transects sampled at that site. 


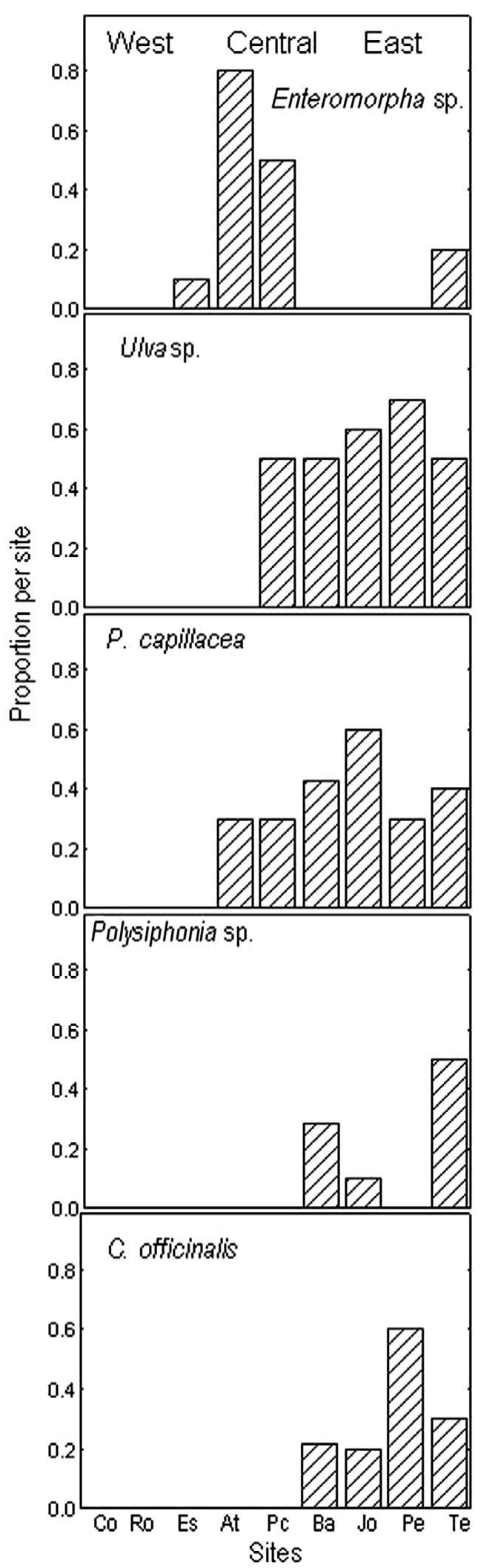

FIG. 7. - Patterns of distribution of selected macroalgal species, as proportions (\# transects occupied / total number of transects). A proportion $=1$ indicates that the species was found in all $(=10)$ transects sampled at that site.

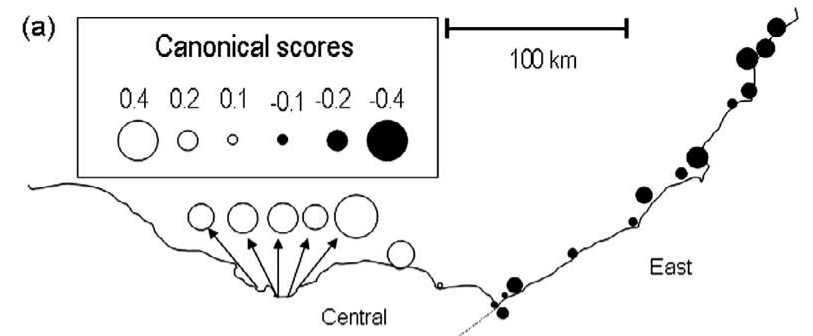

(b)

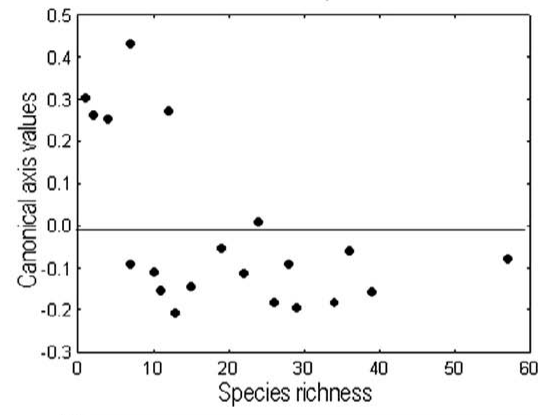

(c)

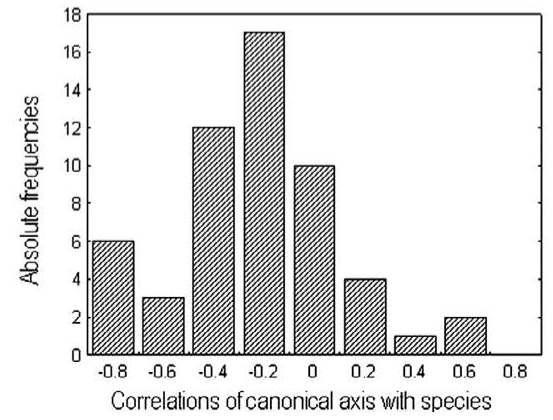

FIG. 8. - Canonical analysis of principal coordinates done on the macroalgal annotated list of the Uruguayan coast (Coll and Olivera, 1999). (a) Canonical scores per site differentiated as negative and positive values; (b) relationship between canonical scores and species richness: (c) absolute frequency distribution of correlations between the first canonical axis and macroalgal species data indicating that for most species the correlations were negative.

in the mussel-algal canopy (Fig. 6, right panel). The two easternmost sites, La Pedrera and Santa Teresa, shared species in low frequency such as the gastropod Echinoilittorina lineolata (Littorina ziczac in Maytía and Scarabino, 1979), the crab Pachycheles haigae, a caprellid amphipod and two undetermined sea anemones. E. lineolata occurred mostly among barnacles or in crevices, $P$. haigae was found mainly within the algal-mussel canopy, and the anemones were found in tide pools or under crevices in the lower intertidal.

Macroalgae did not clearly separate sectors as in the case of fauna. However, Enteromorpha sp. tended to be more common in the central sector, while Ulva sp. and Corallina officinalis characterised the east sector (Fig. 7). Other important algae were Pterocladia capillacea and Polysiphonia sp. Multivariate analysis (CAP) based on the annotated list of macroalgae of the Uruguayan coast showed a significant 
effect of sector, according to a single canonical axis. Locations along the central sector showed all positive values of the canonical axis, while those located in the east sector showed negative values (Fig. 8a). The canonical scores were negatively correlated with the species richness per site (Fig. 8b), suggesting that the observed structure was associated with a reduction of the macroalgae diversity. About $87 \%$ of the macroalgal species had a negative correlation with the canonical axis (Fig. 8c), showing that the structure was due to macroalgae being more frequent in the east sector; the remaining species did not strongly correlate with that axis $(r<0.6)$. Indeed, the assemblage of macroalgae present in the central sector was a subsample of the species pool found in the east sector.

\section{DISCUSSION}

Our results showed a large-scale $(+500 \mathrm{~km})$ pattern of macrobenthic community structure in relation with the salinity gradient produced by the Río de la Plata and the Atlantic Ocean. The gradient led to a linear increase in species diversity with increasing salinity. There was a clear differentiation of freshwater vs. estuarine/marine communities associated with the estuarine front; concerning the outer marine front, there was a differential role of functional groups on the subdivision of estuarine and marine assemblages. At large scales pelagic conditions appear to affect the structure of rocky intertidal communities.

\section{Salinity-richness relationships}

The first clear pattern was an almost linear increase in species richness from freshwater to marine sites. This pattern is robust, as it was significant when we used our records of salinity, the long-term mean values for spring (exception for macroalgae), and maxima or minima. Therefore, the observed pattern may reflect long-term and large-scale variations in environmental conditions existing in the Uruguayan coast.

Freshwater habitats were characterised by a few species, while in estuarine or marine habitats there was a larger number of species. This is consistent with the findings of Maytía and Scarabino (1979) for macrofauna and Coll and Olivera (1999) for macroalgae from estuarine and marine sites. Therefore, the patterns of community structure reported agree with these historical data.
The pattern found here contrasts with that of Remane (Remane and Schlieper, 1971), considered as general for subtidal zones of estuaries, because we did not find a maximum species richness at the freshwater extreme. Therefore, the hypothesis of horohalinicum cannot explain alone the observed patterns: although richness is low at the ecophysiological boundary of $4-8$, it is lower at salinities $<4$. The pattern recorded here does not fit with the one of Attrill (2002): although species richness is low at sites with the high salinity variation, lower values are found at freshwater sites, with low salinity variation. The pattern of species richness instead followed that reported for the Baltic Sea for macroalgae (Wallentinus, 1991). The reason for this discrepancy may lie in the particular conditions characterising the rocky intertidal zone (e.g. desiccation through exposure to air) or the Río de la Plata ecosystem (e.g. high turbidity in the freshwater sector).

\section{Benthic community and fronts: freshwater vs. marine-estuarine communities}

There was a clear differentiation between freshwater and estuarine/marine communities, most likely as a consequence of differential adaptations to salinity conditions. Communities may be differentiated if they have clear habitat boundaries or if they are identified by dominant indicator species (Morin, 1999). Species found in the west sector were all of freshwater origin, differentiating a community separated from those of the central and east sectors. The differentiation of these communities was clearly associated with the area of location of the estuarine fronts and the isohaline of 5 of the Río de la Plata river estuary (Guerrero et al., 1997a; Mianzan et al., 2001): these features are located between Punta Espinillo (easternmost site of west region) and Atlántida (westernmost site of central region).

Differences in abundance between these communities suggest that the local processes affecting them are different. In other regional studies, mesoscale oceanographic structures associated with upwelling or downwelling (Menge et al., 1997, 2003) or wave action (Bustamante and Branch, 1996) affect local processes through changes in the nutrient levels, the larval supply or the trophic structure. In the freshwater habitat, most species were mobile and occupied the upper littoral pools or large crevices, suggesting that desiccation may preclude colonisation of exposed habitats. The lack of a cover of ses- 
sile species on exposed habitats must have limited the distribution of mobile species to littoral pools or crevices. Wave action, responsible for reducing desiccation stress in the higher intertidal zone (Raffaelli and Hawkins, 1996), is low in comparison with that at the estuarine-marine sites. Changes in tidal amplitude should not explain the observed pattern since in the Uruguayan coast the highest tidal amplitude is expected in the west sector $(30-60 \mathrm{~cm}$ in the west sector ca. $15-30 \mathrm{~cm}$ in the central sector and $<15 \mathrm{~cm}$ in the east sector: see O'Connor, 1991). Highly turbid waters in this sector may reduce growth of suspensivores (Robinson et al., 1984; Ellis et al., 2002) and limit primary production. Limits to dispersion of larvae of species with complex life cycles due to differential transport or physiological tolerance should be also taken into account to explain the limits of distribution (Roughgarden et al., 1988; Giménez, 2003).

On the other hand, biological interactions (e.g. facilitation, competition, herbivory) must be important in the estuarine-marine community. Here, sessile species such as barnacles, mussels and macroalgae covered the exposed rocks. Mobile species were not limited to crevices or pools: polychaetes, amphipods and isopods were present within the beds formed by sessile species. These sessile species must act as physical bioengineers (sensu Jones et al., 1994), further increasing the habitat available for mobile fauna. Facilitation by mussels appears to be important in explaining the meso-scale distribution of predatory crabs (Broitman et al., 2001). Recent work shows that mussels play a central role in the patterns of distribution of mobile species on the oceanic coast of Uruguay (Borthagaray and Carranza, 2007).

\section{Benthic community and fronts: functional group-dependent assemblage patterns}

The differentiation among estuarine and marine assemblages roughly corresponds to the sectors defined by Maytía and Scarabino (1979). These two assemblages may not be considered different communities since they shared a large number of species and changes in presence/absence patterns along the shore were gradual. This is consistent with the fact that the gradient in this front extends over a larger distance.

Our analysis suggested that the differentiation depended on the functional group considered. The species that characterised the estuarine sites were all sessile invertebrates, while mobile invertebrates characterised the east sector. Thus, it seems that apart from osmotic stress, the processes affecting mobile fauna and macroalgae are different that those affecting sessile fauna. On the Uruguayan coast there is still no experimental research aimed at evaluating the causes of patterns on rocky shores. Thus, it is only possible to advance hypotheses about the potential processes responsible for these patterns. Sessile species are affected by space competition among other factors (Raffaelli and Hawkins, 1999). The association between $B$. darwinianus, and the epizoic species $B$. improvisus and Membranipora sp. characterising the estuarine sector may be explained as follows: low and variable salinities should exclude the mussels M. edulis, P. perna and $B$. rodriguezi as well as epizoic macroalgae. Such exclusion may favour colonisation of rock surfaces by another mussel, B. darwinianus, and colonisation of mussel surfaces by B. improvisus and Membranipora sp. Both $B$. darwinianus and B. improvisus are ubiquitous intertidal and subtidal estuarine species (Maytía and Scarabino, 1979; Riestra et al., 1992); B. improvisus is a known euryhaline species (Leppäkoski, 1999). Alternatively, colonisation of mussel surfaces by algae and barnacles may depend on the specific host.

A different explanation must be put forward for mobile fauna and macroalgae. On the one hand the observed pattern may be purely a consequence of differential osmotic adaptations or changes in wave action. On the other hand, mobile fauna in particular may be limited by food or habitat conditions provided by macroalgae: grazers such as limpets and littorinid snails should be limited by food sources. These hypotheses should be evaluated by combinations of field and laboratory experimental approaches.

\section{CONCLUSIONS}

In conclusion, large-scale gradients in salinity and near-shore hydrological structures (e.g. fronts) may affect the richness and structure of intertidal communities on the Uruguayan coast. The correlations between species richness and salinity suggest that the combination of salinity and other factors (e.g. turbidity, desiccation) should be taken into account to explain diversity gradients in estuaries. The position of the estuarine front is important to explain horizontal patterns and processes organising these intertidal communities. 


\section{ACKNOWLEDGMENTS}

We appreciate help from Dr. A. Verdi (F. Ciencias, Uruguay) who kindly helped us with the determination of peracarid crustaceans. Dr. D. Calliari and Dr. G. Torres (F. Ciencias Uruguay) corrected earlier versions of the manuscript. Financial support was provided by the PNUD/GEF/RLA G31 project (FREPLATA), a programme for the environmental protection of the Río de la Plata and its Maritime Seaboard, Uruguay-Argentina. AIB is supported by the Millennium Centre for Advanced Studies in Ecology and Research on Biodiversity, ICM P05-002, and the Universidad de Chile and by FONDAP-Fondecyt 1501-0001 to the Centre for Advanced Studies in Ecology and Biodiversity, Pontificia Universidad Católica de Chile.

\section{REFERENCES}

Anderson, M. and T. Willis. - 2003. Canonical Analysis of Principal Coordinates: a Useful Method of Constrained Ordination for Ecology. Ecology, 84: 511-525

Attrill, M. - 2002. A testable linear model for diversity trends in estuaries. J. Anim. Ecol. 71: 262-269

Benedetti-Cecchi, L. - 2001. Variability in abundance of algae and invertebrates at different spatial scales on rocky sea shores. Mar. Ecol. Prog. Ser., 215: 79-92.

Borthagaray, A. and A. Carranza. - 2007. Mussels as ecosystem engineers: Their contribution to species richness in a rocky littoral community. Acta Oecol., 31: 243-250.

Boschi, E., E. Fischbach, and M. Iorio. - 1991. Catálogo ilustrado de los crustáceos estomatópodos y decápodos marinos de $\mathrm{Ar}$ gentina. Frente Marítimo, 10: 7-9.

Broitman, B., S. Navarrete, F. Smith, and S. Gaines. - 2001. Geographic variation of southeastern Pacific intertidal communities. Mar. Ecol. Prog. Ser., 224: 21-34.

Bustamante, R. and G. Branch. - 1996. Large scale patterns and trophic structure of southern African rocky shores: the roles of geographic variation and wave exposure. J. Biogeogr., 23: 339-351.

Coll, J. and E. Olivera. - 1999. The Benthic marine algae of Uruguay. Bot. Mar., 42: 129-135.

Diniz-Filho, J., C. de Santána, M. de Souza and T. Rangel. - 2002. Null models and spatial patterns of species richness in South American birds of prey. Ecol. Lett., 5: 47-55.

Ellis, J., V. Cummings, J. Hewitt, S. Thrush, and A. Norkko. - 2002. Determining effects of suspended sediment on condition of a suspension feeding bivalve (Atrina zelandica): results of a survey, a laboratory experiment and a field transplant experiment. J. Exp. Mar. Biol. Ecol., 267: 147-174.

Framiñan, M. and O. Brown. - 1996. Study of the Río de la Plata turbidity front, Part I: spatial and temporal distribution. Cont. Shelf Res., 16: 1259-1282.

Fraschetti, S., A. Terlizzi and L. Benedetti-Cecchi. - 2005. Patterns of distribution of marine assemblages from rocky shores: evidence of relevant scales of variation. Mar. Ecol. Prog. Ser., 296: 13-29.

Giménez, L. - 2003. Potential effects of physiological plastic responses to salinity on population networks of the estuarine crab Chasmagnathus granulata. Helgol. Mar. Res., 56: 265-273.

Giménez, L., A. Borthagaray, M. Rodríguez, A. Brazeiro and K. Dimitriadis. - 2005. Scale-dependent patterns of macroinfaunal distribution in soft-sediment intertidal habitats along a largescale estuarine gradient. Helgol. Mar. Res., 59: 224-236.
Gotelli, N. and G. Entsminger. - 2004. EcoSim: Null models software for ecology. Version 7. Acquired Intelligence Inc. and Kesey-Bear. Jericho, VT 05465. http://garyentsminger.com/ ecosim/index.htm.

Guerrero, R., E. Acha, M. Framiñan and C. Lasta. - 1997a. Physical oceanography of the Río de la Plata Estuary, Argentina. Cont. Shelf Res., 17: 727-742.

Guerrero, R., C. Lasta, E. Acha, H. Mianzán and M. Framiñan. 1997b. Atlas Hidrográfico del Río de la Plata, Buenos Aires, Argentina-Montevideo, Uruguay.

Hughes, T., H. Baird, E. Dinsdale, A. Moltschaniwskyj, M. Pratchett, J. Tanner and B. Willis. - 1999. Patterns of recruitment and abundance of corals along the Great Barrier Reef. Nature, 397: $59-63$.

Jones, C., J. Lawton and M. Shachak. - 1994. Organisms as ecosystem engineers. Oikos, 69: 373-386.

Lappo, S., E. Morozov, D. Severov, A. Sokov, A. Klyuvitkin and A. Nagy. - 2005. Frontal mixing of river and sea waters in Rio de La Plata. Doklady Earth Sciences. Akademii Nauk, 401: 226-228.

Leppäkoski, E. - 1999. Balanus improvisus (Darwin 1854), Balanidae, Cirripedia. In: S. Gollasch, D. Minchin, H. Rosenthal and M. Voigt (eds.), Exotics Across the Ocean. Case histories on introduced species: their general biology, distribution, range expansion and impact, pp. 49-54. Univ. Kiel, Department of Fishery Biology, Institute for Marine Science.

Mannino, A. and P. Montagna. -1997. Small-scale spatial variation of macrobenthic community structure. Estuaries, 20: 159-173.

Maytía, S. and V. Scarabino. - 1979. Las comunidades del litoral rocoso del Uruguay: zonación, distributción local y consideraciones biogeográficas. In: A. Jensen and J. Stein (eds.), Ecología Bentónica y Sedimentación de la Plataforma Continental del Atlántico Sur, pp. 149-160, UNESCO, Montevideo.

Menge, B., B. Daley, P. Wheeler, E. Dahlhoff, E. Sanford and P. Strub. - 1997. Benthic-pelagic links and rocky intertidal communities: Bottom-up effects on top-down control? Proc. Natl. Acad. Sci. USA, 94: 14530-14535

Menge, B., J. Lubchenco, M. Bracken, F. Chan, M. Foley, T. Freidenburg, S. Gaines, G. Hudson, C. Krenz, H. Leslie, D. Menge, R. Russell and M. Webster. - 2003. Coastal oceanography sets the pace of rocky intertidal community dynamics. Proc. Natl. Acad. Sci. USA, 100: 12229-12234.

Mianzan, H., C. Lasta, E. Acha, R. Guerrero, G. Macchi and C. Bremec. - 2001. The Río de la Plata estuary, Argentina-Uruguay. In: U. Seeliger and B. Kjerfve, (eds.), Coastal Marine Ecosystems of Latin America Berlin, pp. 195-204, SpringerVerlag, Berlin.

Morin, P. - 1999. Community Ecology. Blackwell, Oxford.

Nagy, G., M. Gómez-Erache, C. López and A. Perdomo - 2002. Distribution patterns of nutrients and symptoms of eutrophication in the Río de la Plata estuary system. Hydrobiologia, 475/476: 125-139.

Nonato, E. and C. Amaral. - 1979. Anelídeos Poliquetas. Chaves para famílias e gêneros, São Paulo University, São Paulo, Brazil.

O'Connor, W. - 1991. A numerical model of tides and storm surges in the Rio de la Plata Estuary. Cont. Shelf Res., 11: 1491-1508.

Raffaelli, D. and S. Hawkins. - 1996. Intertidal Ecology. Chapman and Hall, London.

Rangel, T., J. Diniz-Filho and L. Bini. - 2006. Towards an integrated computational tool for spatial analysis in marcoecology and biogeography. Global Ecol. Biogeogr., 15: 321-327.

Remane, A. and C. Schlieper. - 1971. Biology of Brackish Water. E. Schweiserbart'sche Verlagsbuhhandlung, Stuttgart.

Riestra, G., L. Giménez and V. Scarabino. - 1992. Análisis de la comunidad macrobentónica infralitoral de fondo rocoso en Isla Gorriti e Isla de Lobos (Maldonado, Uruguay). Frente Marít., 11: 123-127.

Rios, E. - 1994. Seashells of Brazil. Fundação Universidade de Rio Grande, Museu Oceanográfico, Rio Grande do Sul, Brasil.

Robinson, W., W. Wehling and M. Morse. - 1984. The effect of suspended clay on feeding and digestive efficiency of the surf clam, Spisula solidissima (Dillwyn). J. Exp. Mar. Biol. Ecol., 74: 1-12.

Roughgarden, J., Gaines, S. and H. Possingham. - 1988. Recruitment dynamics in complex life cycles. Science, 241: 1460-2466.

Scarabino, F. - 2004. Lista Sistemática de los Gastropoda marinos y estuarinos vivientes de Uruguay. Comun. Soc. Malac. Uruguay, 8: $305-346$ 
Scarabino, F., J. Zaffaroni, A. Carranza, C. Clavijo, and M. Nin. - 2006. Gasterópodos marinos y estuarinos de la costa uruguaya: faunística, distribución, taxonomía y conservación. In: R. Menafra, L. Rodríguez-Gallego, F. Scarabino, and D. Conde (eds.), Bases Para la Conservación y el Manejo de la Costa Uruguaya., pp. 143-155, Vida Silvestre, Montevideo.

Schneider, D. - 1994. Quantitative Ecology: spatial and temporal scaling. Academic Press, New York.

Severov, D., G. Nagy, V. Pshennikov and E. Morozov. - 2003. SeaWifs fronts of the Rio de la Plata estuarine system. Geophysical Research Abstracts 5, 01914. www.cosis.net/abstracts/ EAE03/01914/EAE03-J-01914.pdf
Wallentinus, I. - 1991. The Balthic Sea gradient. In: A. Mathieson and P. Nienhuis (eds.), Ecosystems of the World, Vol 24, pp. 83-108, Intertidal and littoral systems Elsevier, Amsterdam.

Ysebaert, T., P. Herman, P. Meire, J. Craeymeersch, H. Verbeek and C. Heip. - 2003. Large-scale spatial patterns in estuaries: estuarine macrobenthic communities in the Schelde estuary, NW Europe. Estuar. Coast. Shelf Sci., 57: 335-355.

Zar, J. - 1996. Biostatistics. Prentice-Hall, London.

Scient. ed.: J.S. Troncoso.

Received September 2, 2008. Accepted March 31, 2009.

Published online November 23, 2009. 